\title{
Grundtvig og Det litterære Selskab $1805-1822$
}

\author{
AfFlemming Lundgreen-Nielsen
}

Grundtvig fandt allerede tidligt i sit liv råd for at tilfredsstille sin kolossale læselyst. I barndommen i Udby frem til 1792 måtte faderens bibliotek naturligvis holde for. ${ }^{1}$ I Tyregod drog han $\mathrm{i}$ årene 1792-1798 nytte af sin lærer, pastor Laurits Felds bøger, især dem, denne fik som medlem af en læseforening. ${ }^{2}$ For nylig er Grundtvigs boglån på Aarhus Kathedralskoles bibliotek 17991800 blevet fremdraget af glemslen. ${ }^{3}$ Grundtvig har selv berettet, at han under studietiden ved Københavns Universitet 18001803 ikke straks var klar over universitetsbibliotekets muligheder og i stedet betjente sig af et læsebibliotek. ${ }^{4}$ Det har længe været kendt, at Grundtvig på Langeland 1805-1808 dels havde adgang til at låne læsestof hos grevinde Charlotte Ahlefeldt på Tranekjær, dels stiftede et Læseselskab med øens præster for at få en lejlighed til at se nyudkommen litteratur så hurtigt som muligt. ${ }^{5}$ Desuden begyndte han netop i disse år at grundlægge sin egen bogsamling. ${ }^{6}$ Et fund $\mathrm{i}$ håndskriftsamlingerne på Det kongelige Bibliotek i København kan nu supplere vor viden om Grundtvigs praktiske metoder til at holde sig litterært à jour. Det viser sig nemlig, at Grundtvig i sit første halvandet år som alumne på Valkendorfs kollegium har været medlem af et læseselskab, der havde sit lokalgeografiske centrum på Regensen.

Selskabets papirer er bevaret $i$ tre kapsler og består af en forhandlingsprotokol $\mathrm{i}$ to bind omfattende årene 1806-1822 (NkS

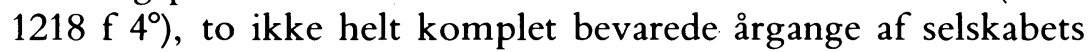
håndskrevne ugeblad, "Rhapsodiske Ideers Tendents", fra 19. januar 1805 til 20. december 1806 ( $\mathrm{NkS} 1218 \mathrm{~g} \mathrm{4^{ \circ }}$ ) og endelig en samling kvitteringer, bilag, regninger, følgeskrivelser, fragmentariske manuskripter (til ugebladsartikler?), cirkulærer, lånesedler og breve fra medlemmer til selskabet ( $\left.\mathrm{NkS} 1218 \mathrm{~h} 4^{\circ}\right)$. Materialet er endt på Det kongelige Bibliotek efter arkivembedsmanden og historikeren M.N. Kall Rasmussen (1816-1863). Han var 
søn af orientalisten, professor, dr. phil. J. L. Rasmussen, der var selskabets Directeur, da det den 13. oktober 1822 indstillede sin virksomhed "for det første" ( 0 : for bestandig).

Foreningen har ikke noget officielt navn. I de latinsprogede dokumenter hedder den Societas litteraria, på dansk kaldes den blot Det litterære Selskab. Fldste bind af forhandlingsprotokollen begynder med et referat af en generalforsamling den 11. april 1806. Det håndskrevne ugeblad omtaler imidlertid (4/11 1805), at selskabet den 27 . oktober 1805 har holdt sit niende møde. Hvis man i første leveår har haft ét møde om måneden, passer det med, at ugebladets no. 1 af årgang 1 er dateret den 19. januar 1805 (og ikke 1. eller 2. januar). Selskabet er da nok grundlagt midt i januar 1805.

Selskabet synes at være vokset frem omkring det håndskrevne ugeblad, der i en række numre refererer generalforsamlingsbeslutninger og klagesager, - stof, der efter april 1806 indføres i forhandlingsprotokollen. Allerede i 1805 har selskabet dog et dobbelt formål: at udgive ugeskriftet og at organisere cirkulation af nyudkomne blade og tidsskrifter. "Rhapsodiske Ideers Tendents " for den 23. februar 1805 indeholder en besværing over et "tilsmudset" og "slemt afjadsket" cirkulationseksemplar af L.N.Fallesens Magazin (o: "Magazin for Religionslærere", fra 1803 med titlen "Theologisk Maanedsskrift for Fædrelandets Religionslærere «). Ugeskriftet går tilsyneladende ind med udløbet af 1806; ingen formel beslutning herom er refereret i protokollen. Det litterære Selskab er fra nu af en ren læseforening.

"Rhapsodiske Ideers Tendents" er i de to årgange ikke videre spændende. Alle numre er forfattet af medlemmerne, men efter selskabets love under streng anonymitet, embedsindlæg fra sekretær eller kasserer dog undtagne. En valgt udgiver renskrev alle indsendte artikler. Anonymiteten kan ikke betragtes som et dække over politisk kontrabande eller frygt for den skærpede trykkefrihedslov af 1799 . Hovedparten af teksterne er studentikost pedantiske drøftelser af ugebladets titel og formål, langtrukne fejdebreve om tidligere indlæg og klager eller forslag angående selskabets drift. Der er også nogle versificerede bidrag, enten komiske fortællinger i Wessels og Baggesens smag, heltedigtning i alexandrinere i Holbergs stil eller viser til gildebrug. Et par gåder og "Charader" hører ligeledes til den komiske gen- 
re. En gennemgående, noget anstrengt serie danner nogle såkaldte "Morsbreve", opkaldt efter et bevidst enfoldigt og derfor satirisk brev i no. 11805 signeret "Niels Kristensen Bogbinder i Thisted ". I det hele er medlemmernes vid nærmest Holbergsk i efterligning af pseudonymerne $i$ indledning og noter til "Peder Paars". Alvorligst ment er nogle oversættelser: af kapitel 22 og 29 hos Epiktet, Vergils 10. ekloge, Bion, Horats' epistler 1. bog 4 og en elegi fra Ovids Amores I.5 (den sidste tabt, men nævnt i en pedantisk antikritik). Omgangsformen i ugebladet er - svarende til forhandlingsprotokollen - præget af udsøgt formel høflighed (de fleste skriver "De" og "Herr») og stor selvhøjtidelighed. Hvis det da ikke er indforstået studenterhumor.

Selskabets love er indskrevet foran i forhandlingsprotokollen og underskrives af det enkelte medlem ved indtrædelsen (desværre uden dato). De er omhyggeligt udformede i 8 paragraffer, som er inddelt i 90 stykker og underafsnit. Selskabet ledes for ét kalenderår ad gangen af en Secretair (fra 13/5 1810 betegnet Directeur), der betaler for bladene og har ansvaret for deres cirkulation $\mathrm{i}$ en portefeuille med låneseddel vedlagt. Der betales kontingent kvartalsvis bagud, og udcirkulerede blade og tidsskrifthæfter sælges på en ligeledes kvartårlig auktion til de fremmødte medlemmer kontant, hvorefter indtægten fordeles ligeligt på medlemmerne. En kasserer, in(d)kassator og auktionarius (i én og samme person) holder regnskab og opkræver mulkter efter en sindrigt specificeret taksttabel. Bøder gives først og fremmest $\mathrm{i}$ forbindelse med for sen aflevering eller tilsøling af bladene. Det første kunne dog undskyldes lovligt med "Veiens Længde", "slet Veir", "Cultus Divinus" eller "Bibellæsning". Regensianere havde på grund af "Veiens Længde" (๖: korthed!) mindre lånetid end folk ude $\mathrm{i}$ byen. Reglerne regner også med, at medlemmer logerer hos andre, i hvilket tilfæelde de må læse det tophemmelige ugeblad hos et medlem med selvstændig bopæl. Dårlige betalere blev hængt ud offentligt, dvs. i den håndskrevne ugeavis, i grove tilfælde udpantet og "infam kasseret ". Sekretæren regerede ved cirkulærer på latin. Nye medlemmer skulle proponeres på en generalforsamling, hvorefter de fremmødte voterede hemmeligt på kort lagt $\mathrm{i}$ en hat. Ved første afstemning indvalgtes man ved simpelt flertal, ved en eventuelt anden kun med $2 / 3$ flertal, ved en eventuelt sidste udelukkende énstem- 
migt. Det er ret almindeligt, at nye medlemmer plumper igennem (lovenes udtryk) i første omgang, men argumenter for og imod refereres ikke. Selskabet talte ved udgangen af 1806 atten medlemmer, men de fleste generalforsamlinger og auktioner frekventeres kun af fra tre til seks medlemmer. Den 29. juni 1814 beslutter man, at selskabet ikke må have mere end tolv medlemmer. Organisationen kan forekomme overdimensioneret. Formentlig har medlemmerne haft deres spas af at tage det hele så højtideligt, som formuleringerne angiver.

Selskabet oplevede flere kriser. I december 1806 forlod elleve medlemmer kredsen for at gå ind i "det academiske Selskab", åbenbart en konkurrent (hvorom intet vides). Man fik kun langsomt suppleret op igen. En sag i august 1810 om en forfalsket billet fra Directeuren til en stud. theol. Hans Jacob Blicher afvistes som private "Kjævlerier", hvorpå Blicher udmeldte sig. I maj-juni 1819 begærer tre medlemmer imod lovene rabat, fordi de bor i samme gade; det afslås, og efter udveksling af polerede ukvemsord tillades det dem ekstraordinært at forlade selskabet, da generalforsamlingen ikke vil tvinge medlemmer af en så lav logisk og moralsk standard til at blive.

Også kriser i omverdenen slog ind i selskabet. Den 14. februar 1813 vedtog en generalforsamling, at mulkter i fremtiden skal betales i "Rigsbankpenge, Skilling for Skilling", en følge af Frederik VIs pengeforordning af 5. januar 1813 (den såkaldte Statsbankerot). Den 25. oktober 1818 forhøjer en generalforsamling med tre stemmer mod én alle forordnede mulkter til det dobbelte i sølv, så f.eks. 2 skilling N.V. (o: Navne-Værdi) bliver til 4 skilling sølv, og alle brøker rundes op til nærmeste hele tal, til tab for mulktyderne. Dette afspejler, at Nationalbanken, der var oprettet pr. 1. august 1818, var gået over til sølvmøntfod.

Medlemmerne af selskabet er fortrinsvis teologi-, jura- og filosofi-studerende, men der er også nogle akademisk uddannede embedsmænd i bureaukratiets nederste lag. Få af navnene ud over Grundtvig, B.S. Ingemann, den nævnte orientalist J.L. Rasmussen og skolemanden N.W. Dorph kendes idag. Stud. theol. H.D. Uldall, optaget den 12. juni 1812, dukker op som underskriver på Grundtvigs Helligtrekongermanifest i januar $1813 .^{7}$ Andre figurerer siden på lister og breve omkring Grundtvigs oversættelse og uddeling af Saxo og Snorro 1815-1823. 
Stud. theol. J.H. Edsberg, som var den, der skaffede Grundtvig posten på Egeløkke, var medlem af selskabet til og med 1806, men Grundtvig har netop pointeret, at Edsberg var ham hartad ubekendt. ${ }^{8}$

$\mathrm{Nu}$ til Grundtvigs forhold til selskabet. Grundtvig ankom den 1. maj 1808 fra Egeløkke til hovedstaden. Den 25. maj kunne han rykke ind på en friplads på Valkendorfs kollegium i Skt. Pedersstræde for $\mathrm{i}$ ro og mag at fortsætte sin videnskabelige behandling af Nordens mytologi og oldtidshistorie. Skønt Grundtvig i et brev den 4. juni 1808 til P.N. Skougaard taler om en "Kondisjon i Frederiksberg" (om hvilken intet andet vides) har han utvivlsomt måttet klare sig uden penge til andet end det mest nødvendige. Han kunne have gode grunde til at melde sig ind $\mathrm{i}$ en sammenskudsforening som Det litterære Selskab.

Selskabets forhandlingsprotokol meddeler, at "Hr. Cand: Theologix N.F. Grundtvig " den 26. juni $1808^{10}$ blev proponeret, men forkastet med to stemmer mod én; mødedeltagere var teologistudenterne P.C. Thørche, H.J. Fich og J. Paludan. ${ }^{11}$ I en anden omgang blev han så den 3. juli indvalgt med fire stemmer mod én, af Thørche, Fich, Paludan, P. Blicher og Peter Worm.

Grundtvig blev medlem på et tidspunkt, hvor selskabet endnu ikke var kommet til kræfter efter medlemsudvandringen i december 1806. Mens man i 1806 havde holdt hele ti aviser og tidsskrifter, abonnerede selskabet i 1808 kun på Rahbeks "Nye danske Tilskuer" (1807 f.), Odin Wolfs »Journal for Politik, Natur- og Menneske-Kundskab“ (1804 ff.), Laur. Engelstofts "Universitets og Skole-Annaler" (1806 ff.) og Det skandinaviske Literaturselskabs skriftrække (1805 ff.). På det møde, der optog Grundtvig, vedtog man at subskribere på avisen "Nyeste Skilderie af Kjøbenhavn" (1804 ff.) i stedet for Rahbeks "Tilskuer " (der ophørte i og med årgang 1808).

Den 22. september 1808 vedtog en generalforsamling at holde Rahbeks "Ny Minerva", en beslutning, Grundtvig har medunderskrevet i protokollen. Det er vist det eneste møde, han har deltaget i. Måske er ideen hans: seks af hans afhandlinger fra Egeløkke-tiden var jo fremkommet i Rahbeks månedsskrift. Men "Ny Minerva " gik også ind i og med årgang 1808. Den 30. december 1808 tillader en generalforsamling, at "Ny Minerva " kan beholdes tre dage, men at overskridelse af lånet mulkteres 
med 2 skilling pr. dag (mod normalt 1). Grundtvig har ikke medunderskrevet og var vel ikke til stede. Endelig vedtages det $\mathrm{i}$ Grundtvigs medlemsperiode, nemlig 20. december 1809, at man skal holde "Kiøbenhavnske lærde Efterretninger" (1791 ff.) regulært og ikke længere betale et medlem (O.M. Platou) for at læse dem.

Selskabets arkiv nævner ingen tidsskrifter, vi ikke i forvejen vidste, Grundtvig fulgte med i. Men nu véd vi altså hvorledes. Noget synderlig aktivt medlem har han ikke været. Han er dog fra den 16. juli 1808 til den 5. januar 1810 blevet noteret for sin part af mulkterne, i alt 37 på de forordnede småbeløb. Det er snarere under end over gennemsnittet. Desværre opererer mulktregnskaberne kun med løbenumre på lånesedler, dato for forseelsen og beløbet. Derfor er det ikke muligt at konstatere, hvilke tidsskrifter Grundtvig har beholdt for længe. Han har punktligt indbetalt såvel sine mulkter som sine kontingenter. Derimod har han aldrig købt noget på auktionerne. Der føres ikke regnskab med fordelingen af auktions- og mulktindtægter til medlemmerne. Men det er muligt, at Grundtvigs personlige økonomiske mellemværende med selskabet har balanceret, - at han altså har læst med gratis.

I efteråret 1808 tilknyttedes Grundtvig som bekendt privatskolen Det Schouboeske Institut. ${ }^{12}$ Det har på en regelmæssig måde givet ham penge mellem hænderne. Hans aldrig varme forhold til Det litterære Selskab kølnes yderligere. Den 15. december 1809 skriver Grundtvig fra Skt. Pedersstræde til selskabets sekretær i St. Kannikestræde. Det hidtil ukendte brev i bilagskapslen lyder:

Valkendorfs Kollegium $15^{\text {de }}$ Decbr 1809 Medfølgende Pakker giver jeg mig den Frihed at sende Dem, da jeg ei veed, hvor de skulle leveres.

Derhos beder jeg ogsaa, at ingen flere maa vorde mig sendte, da Tiden ei tillader mig at besørge dem! At jeg imidlertid er villig til at betale for saa lang Tid, som Lovene maatte foreskrive, følger af sig selv -

S.T.

Hr Studiosus Thørke

ærbødigst

Grundtvig

paa

Regensen 
Grundtvig havde virkelig voldsomt travlt i december 1809. Efter en "Dumhed" og "Hovedskade" i sommeren $1809^{13}$ var han i et skarpt og vittigt svar på den vrantne historiker G.L. Badens angreb på "Nordens Mytologi “ 1808 atter tilbage på den københavnske litterære slagmark. "Optrin af Kæmpelivets Undergang i Nord " udkom i december, og Grundtvig håbede sikkert endnu på de anmeldelser og den omtale i pressen, der ikke kom. To sagapasticher, "Odins Komme til Norden" og "Sværdet Tirfing ", var næsten færdige som en fortsættelse af "Optrin ", og et fragmentarisk drama af norsk historie. "Hakon Adelsteen Norrigs Konge", hører sandsynligvis også til de sidste måneder af 1809 sammen med en håndfuld utrykte manuskripter angående Saxo og Snorre. ${ }^{14}$ Hertil kom så planer om at oversætte Den ældre Edda og at udgive et kulturtidsskrift i forening med kollegiekammeraten F.C. Sibbern. Grundtvig kunne ikke længere finde tid til at ekspedere læseselskabets portefeuiller med cirkulationsmaterialet.

Den 1. februar 1810 meddeler forhandlingsprotokollen, at Grundtvig er udtrådt af selskabet pr. 1 januar. Han efterbetalte i løbet af det næste halve år både mulkter og kontingenter og var den 21. juni 1810 så endeligt ude af selskabet.

Dermed var selskabet dog ikke færdig med Grundtvig. I et referat af en generalforsamling den 19. april 1810 beretter protokollen under punkt 2: "Voteredes paa om ikke Selskabet skulle holde Odin og Saga af: DHrr Grundtvig og Sibbern. - Dette kunde ikke afgjøres da 2 Stemmer vare for og 2 imod Forslaget. - ". Til stede var Thørche, N. Koch, S. Benzon og P.E. Benzon. Det manglende flertal på mødet for eksmedlemmets subskriptionstilbud var således medvirkende til, at "Odin og Saga " aldrig blev til virkelighed. ${ }^{15}$

Større gensidig kærlighed fornemmes mellem selskabet og dets andet berømte medlem, "Hr Candidatus Philosophiæ B.S. Ingemann", der den 9. februar 1812 optoges énstemmigt. Den 29. september 1813 vedtog en generalforsamling, at man i fremtiden skulde indkøbe "enkelte nye danske udkommende Bøger" af formentlig "almeen Interesse. "Dermed fik Ingemann med sin voldsomme produktivitet i 1810 'erne en chance, Grundtvig ikke havde i sin medlemsperiode. Således melder forhandlingsprotokollen i 1814: "Den $10^{\text {de }}$ Junii havde Hr Ingemann den Godhed at 
overlevere Directeuren sit nyelig udkomne romantiske Epos: De sorte Riddere til Circulation blandt Selskabets Medlemmer. - ". Den 4. marts 1815 står sammesteds at læse, at det énstemmigt vedtoges at købe "de to Sørgespil, Masaniello og Blanca af Ingemann «; den 11. marts 1815 betaler Directeuren 4 Rbdl og 1 Mark for "Masaniello", mens "Blanca blev overladt Selskabet tillaans af Forfatteren, Selskabets hoderlige Medlem, Herr Ingemann. - ". Ingemann udtrådte af selskabet $\mathrm{i}$ og med udløbet af tredie kvartal af 1815 (protokollen 27/9 dette år). I lighed med Grundtvig har Ingemann aldrig anskaffet sig noget på selskabets kvartårlige auktioner. Men i hvert fald i 1814 har han deltaget $i$ fire af møderne $(16 / 2,30 / 3,13 / 12$ og 28/12). Selskabet vedblev at følge hans forfatterskab (dato for første omtale i parentes, bogstaveringen er protokollens): man anskaffede "Røsten i Ørkenen" (19/11 1815), "Reinald Underbarnet " (27/12 1815), "Hyrden af Tolosa " (7/7 1816), "Løveridderen" (29/12 1816), "Tassos Befrielse" (20/10 1819), "Eventyr" (7/4 1820), "Reiselyren" I (5/9 1820), "Kampen for Valhal" (15/6 1821), "Magnetismen i Barberstuen" (4/7 1821) og "Reiselyren" II (7/12 1821). Af Ingemanns produktion efter 1815 mangler således blot digtsamlingen "Julegave" (1816) og eventyret "De Underjordiske"(1817).

I det hele taget behøver Det litterære Selskab ikke skamme sig over sin vurdering af, hvilke titler der kan siges at have almen interesse. Man udtog således bl.a.: Baggesens "Søndagen" (16/2 1814), "Poetiske Epistler" (1/12 1814) og "Danfana" (27/12 1815 , opsagt 8/6 1817), S.S. Blichers "Digte" (1/12 1814), Elmquists "Læsefrugter" (30/6 1819), J.L. Heibergs "Marionettheatret" (11/5 1814) og "Tycho Brahes Dom" (28/1 1819), Finn Màgnussens "Den ældre Edda "I-III (14/1 1821, 13/11 1821, 30/6 1822, samt G.L. Badens pjece herimod 20/3 1821 med svarpjecen fra Magnussen af 12/4), C. Molbechs "Athene" (20/9 1813) og "Reisen i Sverrige" (20/3 1818), Rasmus Nyerups "Danske Viser" (4/11 1821), Rahbeks "Den danske Tilskuer" (1/2 1815) og "Nye Minerva" (3/6 1815) og hans og Nyerups "Den danske poetiske Literaturs Historie indtil Tullin" (20/3 1818), Steens "Adrastea" (14/12 1815), N. Søetofts "Aandernes Maskerade" (8/7 1816), J.M. Thieles "Folkesagn" I-III (20/9 1818, 6/5 1819, 20/12 1820) og "Pilegrimmen" (4/3 1820), "Videnskabelige Forhandlinger ved Siellands Stifts Landemode" (9/2 1812) og ende- 
lig Oehlenschlägers "H.v. Reinberg“ (24/12 1813), "Fortællinger" (24/12 1813), "Digtninger" II (11/5 1814), "Ludlams Hule" (11/5 1814), "Røverborgen " (1/12 1814), "Fostbrødrene" (20/3 1818), "Reise" II (11/10 1818), "Nordens Guder" (7/6 1819), "Erik og Abel " (3/7 1820) og "Tordenskiold “ (8/6 1821). Tylvtefejden mellem Baggesen og Oehlenschlägerianerne i efteråret 1818 har selskabet fulgt tæt: Baggesens "Breve til Oehlenschläger" $(3 / 8,11 / 9,21 / 9,30 / 9,10 / 10,1 / 11,10 / 11)$, "Reisen i Udtog" (2/10) og "Rosenblade" (28/3 1819), Carsten Hauchs "Om Baggesens Breve" (15/10), "Iris" (22/1 1819) og "Hermes (28/3 1819), den fælles "Giendrivelse fra de Tolv" (18/11 1818) og Oehlenschlägers "Svar til Baggesen" (21/12 1818) er indkøbt.

Selskabets eksmedlem, Cand: Theologiæ N.F. Grundtvig er mindre dækkende repræsenteret. Af ham har man erhvervet: "Roskilde-Riim" (11/5 1814), "Hvem er den falske Prophet?" (14/5 1814), "Skal vi troe paa Gud eller Athene?" (22/8 1814, sammen med H.C. Ørsteds "Imod den store Anklager", efter protokollen "begge extraordinair anskaffede"), "Heimdall " (26/3 1816), "Literaturtidendens Skudsmaal" (28/6 1816, sammen med P.E. Müllers "Tillæg til Müllers Recension over Saxo og Snorro") og "Biowulfs Drape" (24/9 1820).

Man har tilsyneladende ikke interesseret sig for Grundtvigs verdenskrøniker 1814 og 1817, ikke for "Roskilde-Saga " 1814 eller "Kvædlinger" 1815, ikke for "Bibelske Prædikener" 1816. Man har ikke abonneret på "Danne-Virke" 1816-1819, skønt Grundtvig selv har oplyst, at flertallet af hans læsere var studerende. ${ }^{16} \mathrm{Og}$ selskabet har ikke som sådant engageret sig i Grundtvigs, Prams og Treschows store projekt omkring fordanskningen og den følgende distribution af Saxo og Snorro i årene 1815-1823.

Det er tvivlsomt, hvad man skal læse ud heraf. Enten købte de studerende og de unge akademikere selv de pågældende skrifter af Grundtvig, eller også har han med sin først fremfarende, så dunkelt poetiserende og mytologiserende holdning i 1810'erne forekommet for uvidenskabelig for den svindende skare medlemmer af Societas litteraria. For den første mulighed taler, at regensianerne, heriblandt nogle af selskabets medlemmer efter Grundtvigs tid, giver flere slet ikke små beløb til Saxo-Snorroprojektet i årene fra $1815 .{ }^{17}$ På den anden mulighed peger den 
kendsgerning, at "Den ældre Edda " ved Grundtvigs videnskabelige rival Finn Magnussen er en af selskabets sidste boganskaffelser.

Fra det beskedne lærdomshistoriske niveau, hvor denne læseforening i det københavnske latinerkvarter afgjort hører hjemme, kan der således gives nogle antydninger af både Grundtvigs forhold til omverdenen i 1808-1810 og omverdenens opfattelse af ham og hans forfatterskab i 1810 'erne frem til opløsningen af Det litterære Selskab i 1822.

\section{Noter}

1. N.F.S. Grundtvig: Dag- og Udtogsbøger, ved Gustav Albeck, I, 1979, s. 44, og William Michelsen: Tilblivelsen af Grundtvigs historiesyn, 1954, s. $56 \mathrm{ff}$.

2. Dag- og Udtogsbøger, I, 1979, s. 46. - Efter Laurits Feld, der døde i 1803, er der fundet en registrant over dennes private bogsamling med en skønsmæssig værdiansættelse af hver bog. Listen omfatter 116 titler, 1 i folio, 29 i kvart, 86 i oktav. Størsteparten er teologiske værker, skolebøger og ordbøger. Feld har ejet Johan Grundtvigs Catechismi Forklaring fra 1779. I hans bibliotek har der også været et eksemplar af Finnur Jónssons Historia ecclesiastica Islandiæ, I-IV, 1772-78, - den bog Grundtvig i sommeren 1804 fandt $i$ sin faders reoler i Udby og lærte sig islandsk efter. Kun en halv snes bøger falder uden for de nævnte teksttyper, således Johan Grundtvigs oversættelse fra 1785 af Phædri Æsopiske Fabler, Ovids Breve fra Ponto samt nogle praktisk orienterede skrifter om biavl, ager- og havedyrkning, kvægsyge og sygdomme. Listen nævner afsluttende, men desværre uden specifikationer, 4 bundter danske bøger. En afskrift af listen er venligt overladt Grundtvig-Selskabet af Feldkenderen, pastor Poul Værge.

3. Dag- og Udtogsbøger, II, 1979, s. 9-10; udnyttet Fl. Lundgreen-Nielsen: Det handlende ord, 1980 , s. 42-44.

4. Dag- og Udtogsbøger, I, 1979, s. 62.

5. F. Ahlefeldt-Laurvig: Generalen, III, 1929, s. 251 ff., V, 1931, s. 191 og 204. Protokol for Langelands Læseselskab, ved Johan Grundtvig, i: Den Danske Højskole, III, 1903, s. 146-186.

6. Fl. Lundgreen-Nielsen: Det handlende ord, 1980, s. $162 \mathrm{f}$.

7. Nik. Fred. Sev. Grundtvigs Udvalgte Skrifter, ved Holger Begtrup, III, 1905, s. 40.

8. Dag- og Udtogsbøger, I, 1979, s. 181 og 381.

9. Breve fra og til N.F.S. Grundtvig, udgivne af Georg Christensen og Stener Grundtvig, I, 1924, s. $15 \mathrm{f}$.

10. Protokolfører Thørche kludrer i datoerne. Mødet er indkaldt den 24. juni til den 26., men referatet af det er alligevel dateret den 24 .

11. Peter Christian Thørche (1783-1850) bliver teologisk kandidat i 1816 og er præst fra 1817.

H.J. Fich (1784-1852) bliver teologisk kandidat i 1810 og i 1822 præst i Bogense. Julius Frederik Paludan (1787-1851) bliver teologisk kandidat i 1810 og ender som præst i forskellige norske kald. 
12. K.E. Bugge: Skolen for Livet, 1965, s. $127 \mathrm{ff}$.

13. Christian Molbech og Nikolai Frederik Severin Grundtvig. En Brevvexling, ved L. Schrøder, 1888, s. $40 \mathrm{f}$.

14. Fl. Lundgreen-Nielsen: Det handlende ord, 1980, s. 307-313.

15. Fl. Lundgreen-Nielsen: "Odin og Saga " genfundet. En Grundtvig-tekst fra 1810, i: Grundtvig-Studier 1979, s. 10-16.

16. Nik. Fred. Sev. Grundtvigs Udvalgte Skrifter, III, 1905, s. 558.

17. I materialet i Grundtvig-arkivet, Det kgl. Bibliotek, København, omkring SaxoSnorro-projektet findes i Fasc. 247,2 og Fasc. 249 følgende navne på studenterbidragydere, der også i 1810'erne var medlem af Det litterære Selskab: C. Fasting, H. Fangel, Jens Westengaard, Schiødte og L. Foss. 